\title{
ARCHEOLOGICKÝ VÝZKUM VYŠEHRADU V LETECH 1924-1936
}

\author{
LADISLAV VARADZIN
}

\begin{abstract}
Abstrakt: V letech 1924-1936 proběhl na Vyšehradě jeden z nejrozsáhlejších terénních výzkumů prvorepublikového Československa, který znamenal značné nároky na personálni a finanční kapacity a na soudobé metodické postupy. V tomto textu se pokouším odpovědět na otázku, jak se tehdejši česká archeologická obec zhostila této výzvy na lokalitěs neoddiskutovatelnou národni aureolou, která přitom zároveň obsahuje radu středověkých až novověkých terénů a nálezů. Na základě autentické dokumentace se současně pokoušim nastínit, jak rekonstrukce činnosti Komise pro výzkum Vyšehradu může charakterizovat metodiku terénního výzkumu tehdejši české archeologie, a také způsob, jakým Komise vnímala svou celospolečenskou úlohu.
\end{abstract}

Klíčová slova: archeologie středověku - metody archeologického výzkumu - nacionalismus - Vyšehrad prvni republika.

\section{Archaeological research of Vyšehrad, 1924-1936}

\begin{abstract}
Some of the most extensive excavations in Czechoslovakia in the First Republic period were conducted at Vyšehrad, Prague in 1924-1936. They were highly demanding in terms of workforce and finance and involved the latest methodological procedures. The article seeks to answer the question of how Czechoslovak archaeologists handled this challenge, on a site of such great historical importance for the Czech nation which, in addition, yielded a number of medieval and modern-age artefacts. Based on authentic documentation, the author outlines how the reconstruction of the activities of the Vyšehrad Research Committee could characterize the methodology of field survey in Czech archaeology of the period, as well as the manner in which the committee viewed its political role.
\end{abstract}

Key words: medieval archaeology - methods of archaeological research - nationalism - Vyšehrad - First Czechoslovak Republic.

\section{Okolnosti výzkumu}

Pevnost Vyšehrad byla zrušena roku 1866, ale pod vojenskou správou zůstala až do roku 1911, kdy teprve byly pevnostní objekty předány Praze. ${ }^{1}$ To ihned probudilo zájem stavitelů a plánovačů, z nichž někteří dokonce navrhovali odstranit barokní hradby a zastavět Vyšehrad činžovními nebo rodinnými domy. Na obranu Vyšehradu však rozhodně vystoupily některé kulturní autority, jako byl Josef Chochol (Klub Za starou Prahu) a především Jan Lier, dramaturg Národního divadla a břitký fejetonista (Ježková 2012). Posledně jmenovaný, v tomto úsilí patrně nejúspěšnější (Ježková 2012), vyjádřil v brilantním článku pro časopis Zvon (č. 11, rok 1910/1911, 11-13) dva hlavní důvody, proč Vyšehrad „,nemá být zbaven své vznositosti a rázovitosti“ a „snižen na beztvarý pahorek, dobrý za rejdiště hejna rodinných domkư": první byly finance a druhý estetické ohledy. Kromě pragmatických důvodů však Lier neváhal apelovat ani na národní city: „Historické a národni momenty pronikavého významu vyžaduji“", aby „Vyšehrad, svatý celému národu, týn Libušin, mohyla naši jaré minulosti, posvěcená vzpomínkami, radostmi i strastmi všech nás" zůstal nezastavěn. „Praga caput regni. Rozvalení Vyšehradu bylo by kusem sebevražedné dekapitalisace Prahy, bylo by dalšim krokem k jejímu sniženi za administrativni středisko c. k. rakouských úr̆adi $v$ Čechách, k jejímu rozparcelování na holou sbirku popisných čísel.“ Jak vidíme, autor neváhal použít argumentaci těžkého kalibru (celý text přetištěn v Ježková 2012).

Proč tento úvod? Uvedený spor nakonec Jan Lier, Josef Chochol a další činovníci vyhráli, a napomohli tak rozhodnutí proměnit Vyšehrad v klidový městský areál, což bylo klíčovou podmínkou pro zahájení zdejšího archeologického výzkumu v roce 1924. Zároveň ale vidíme, že použití

$1 \mathrm{~K}$ napsání tohoto textu jsem byl vyzván organizátory 51. konference Archaeologia historica věnované 100letému výročí Archeologického ústavu AV ČR (původně Státního archeologického ústavu). Chtěl bych poděkovat dr. Ivaně Boháčové a dr. Václavu Mouchovi, kteři mi poskytli některé archivní materiály nebo mě na ně upozornili. 
historické památky k probuzení národního svědomí bylo v roce 1910 stále ještě natolik silnou zbraní, že dokázalo pohnout úředními místy. Výzkum na Vyšehradě v letech 1924-1936, který je předmětem tohoto textu, probíhal rovněž za značného zájmu široké veřejnosti, takže se lze ptát, zda i archeologie v mladém Československu využila nacionálních emocí k propagaci své společenské úlohy.

K rekultivaci Vyšehradu do podoby veřejného parku mohly příslušné orgány přistoupit až po první světové válce a vzniku Československa. Státní regulační komise pro Hlavní město Prahu s okolím se při tom jednoznačně držela přesvědčení, že vyhlášení soutěže na regulační a zastavovací plán se nemůže obejít bez provedení archeologického výzkumu, který bychom dnes nazvali jako ,plošný, systematický, předstihový“. V dokumentech se k tomu píše: „Státní regulačni komise (...) potřebuje i podklady (...), jež by byly výsledkem archeologického prozkoumáni tohoto území. Bez dưkladného prozkoumáni archeologického nelze přistoupiti ku vypracováni návrhu na úpravu tohoto významného území.“2 Impulzem k zahájení výzkumu tedy byly zjevně pragmatické důvody „,památkářského“ charakteru, nikoliv touha odkrývat národní minulost nebo dokládat starobylost českého národa.

Regulační komise se $\mathrm{v}$ roce 1923 obrací na Ministerstvo školství a národní osvěty (MŠANO) s žádostí o ,archeologické prozkoumání územi“ Vyšehradu a to se zase obrací na ředitelství Státního archeologického ústavu s prosbou, aby „,neprodleně zahájilo jednánís př́islušnými činiteli (obec pražská, kapitula vyšehradská [vlastníci pozemků na Vyšehradě]), aby svolili $k$ archeologickému bádáni (...), a předložilo (...) co nejdřive program prací výzkumných a návrh na úhradu nákladů s tím spojených." (Moucha-Nechvátal 2015, 23). Lze si povšimnout, že žádná z uvedených státních institucí v dokumentech nevystupuje v roli investora a že na Státní archeologický ústav spadlo kromě řešení odborných otázek i finanční pokrytí celé akce.

\section{Organizační zajištění}

Úkol to byl po všech stránkách nelehký. Pouhých pět let po svém založení měl Státní archeologický ústav zorganizovat a provést jeden z největších systematických výzkumů meziválečného Československa, s jakými však ještě neměl žádné zkušenosti (rozsáhlé výzkumy na Pražském hradě a ve Stradonicích jsou až pozdějšího data). Přesto ředitel ústavu Lubor Niederle odpověděl na výzvu ministerstva obratem kladně a týž měsíc svolal ustavující schůzi Vyšehradské komise Státního archeologického ústavu (dále jen Komise) sestávající z 31 zástupců z 16 různých institucí. Výzkum zjevně naprosto přesahoval personální a materiální možnosti ústavu, a nebyl možný bez součinnosti několika institucí.

Způsob, jakým Komise řešila financování celého projektu, který nakonec trval třináct roků, a také nejrůznější př̌kážky, kterým v průběhu času musela čelit, včetně hospodářské krize na počátku 30. let, důkladně popsal Václav Moucha ve své studii z roku 2015 (Moucha-Nechvátal 2015). Na tomto místě alespoň připomínám jména klíčových aktérů Komise, kteří stáli „v první linii“: Karla Gutha, Albína Stockého, Karla Buchtelu, Rudolfa Hlubinku a Eduarda Šittlera, ti všichni byli dobře zavedenými osobnostmi české archeologie nebo památkové péče. Vlastní vedoucí terénních výzkumů, kteří v dobových dokumentech vystupují pod méně vznosným označením „asistenti výzkumu“, pocházeli naproti tomu z řad čerstvých absolventů archeologie na pražské fakultě, čemuž odpovídal jejich věk přesahující jen o něco málo dvacítku. V roce 1924 to byli Jaroslav Böhm (1901-1962) a Jan Filip (1900-1981); v roce 1925 Miodrag Grbić (1901-1969, později významný srbský specialista na balkánský neolit); v roce 1926 Stanislav F. Svoboda (1904-1985, později vedoucí národopisného oddělení Národního muzea); v roce 1927 Josef Vacek (1900-1962, po válce obět' vykonstruovaného politického procesu) a nakonec v letech 1928-1934 Jiří Müller (1899-1967, později pracovník Náprstkova muzea). Všichni asistenti získali své první ostruhy při vedení terénního výzkumu právě na vyšehradské půdě. $Z$ uvedených let jejich působnosti na Vyšehradě vyplývá značná oscilace těchto fakticky klíčových pracovníků, což jistě nepřispívalo k systematickému rozvíjení otázek svázaných s problematikou terénního výzkumu.

2 MŠANO, č. j. 1885/23 ze dne 20. 10. 1923. 
Dlouhodobě - a mám pocit, že i nejintenzivněji - se vyšehradským výzkumem zabýval Jiří Müller, který na hradišti strávil sedm po sobě jdoucích let.

\section{Strategie výzkumu}

Jedním z hlavních bodů první plenární schůze Komise konané v lednu 1924 bylo vypracování strategie výzkumu (Moucha 2015, 26). Př́islušný dokument se však zatím nepodařilo nalézt, takže badatelské cíle a způsob, jakým je Komise chtěla realizovat, musíme rekonstruovat z různých zmínek v oficiálních i neoficiálních pramenech a z postupu terénních prací.

Na počátku rozhodně nechybělo sebevědomí. V článku v Lidových novinách z 10. listopadu 1924 popisujícím proběhnuvší první výzkumnou sezónu píše Jaroslav Böhm: „Česká archeologie, moderní, theoreticky důkladně vyzbrojená, má tu po prvé možnost přikročiti u nás $k$ větš́i práci výzkumné, má tu po prvé př́ležitost uplatniti se v praksi. Dosud té možnosti neměla, nebot' k projektům většího stylu scházelo peněz.“ A přiblíženy jsou i hlavní cíle: „poznání historie Vyšehradu, zejména jejich dodnes neznámých počátkü“ a ,(...) podrobnějši poznání topografie starého Vyšehradu a určení jeho jednotlivých stavebnich period“".

Kde ale začít kopat na ohromných, téměř desetihektarových plochách najednou př́stupných výzkumu? Jasné to bylo v místech již známých památek, jako byly rotunda sv. Martina nebo bazilika sv. Vavřince, kde se také výzkum záhy rozvinul. Naproti tomu v př́ípadě dvouhektarové, archeologicky zcela neznámé akropole (označované tehdy jako citadela) bylo potřeba hlubší rozvahy. $Z$ dokumentů jasně vyplývá, že výzkumu předcházela důkladná rešerše písemných a ikonografických pramenů. Jako klíčový byl např́iklad shledán tzv. Malý Sadelerův prospekt z roku $1606,{ }^{3}$ který ,snad nejautentičtěji zobrazuje ještě dvouposchod’ovou ruinu hradiště, jejiž zdivo bylo později bouráno (...)“4 (obr. 1). Komise dospěla ke správnému závěru, že jde o paláce z doby Karla IV., a nepřekvapuje proto, že první sonda na akropoli byla otevřena v místech, kde se k sobě na prospektu přibližují dvě z těchto staveb (označované dnes jako paláce č. 2 a 3). Komise si na akropoli dále vytkla nalézt Kosmou zmíněný a v dobové umělecko-historické literatuře často diskutovaný ,palác, v r. 1119 vichrem pobořeny", „románskou rotundu sv. Jana Evangelisty (...) in curia regis“" (připomínanou v listinách z poloviny 13. století), ,starou školu vyšehradskou v 17. století zbořenou“ (zmíněnou a lokalizovanou V. Rufferem 1861) a zjištěn měl být také ,stav vyšehradského hradu ze slovanské doby hradištni“.5. Komise se tedy rozhodla pro rozvíjení výzkumu vždy od skutečností nějak známých (v tomto př́ípadě vesměs staveb), což je cesta ve většině vědeckého počínání nepochybně nejrozumnější. Tento postup by bylo možné ještě detailněji demonstrovat na mapě sond a na pořadí a poloze jejich vzniku (Varadzin 2015). Jakmile došlo k nečekaným objevům, jako byl např́klad nález románského mostu nebo pravěkých pozůstatků, byly ihned zařazeny do výzkumného plánu.

\section{Metody terénního výzkumu}

Jenom na akropoli otevřela Komise celkem 67 sond o rozloze $4400 \mathrm{~m}^{2}$, které zasahovaly až ke geologickému podkladu, leckdy v hloubce dvou či více metrů. Prováděla výkopy na akropoli, u sv. Vavřince, u sv. Martina, v Karlachových sadech, u brány Špičky a na dalších místech, v několika prrípadech paralelně pod vedením jednotlivých asistentů. Již jen z toho je zř̌jmé, jak náročná organizace prací z toho vyplývala. Kupodivu ale sondy nebyly označovány jednotným ani jednoduchým způsobem. V denících se setkáváme s plejádou označení sond jako výkop „u hydrantu“, „pobliž hradby cvičiště“, „u vrat Zbrojnice“ nebo „před sv. Vavřincem v Soběslavově ulici“ apod. Zjistit zpětně, o jaké sondy vlastně jde na dochovaných plánech nebo fotografích, je často práce

3 Použití této rytiny je výslovně uvedeno v záznamu o exkurzi dr. Říhy s p. kancléřem na Vyšehradě ze dne 19. 6. 1924: „Nad Libušinou lázní podniknut byl hluboký výkop, při čemž se postupovalo podle Sadelerovy rytiny za tím účelem, aby byl odkryt zbytek původního paláce (...)“ (Fond Kancelář prezidenta republiky, inv. č. 970, sign. D1177/34).

4 Jaroslav Böhm, Lidové noviny ze dne 10. 11. 1924.

5 MŠANO, „Pracovní a finanční rozvaha z Komise pro výzkum Vyšehradu“. 


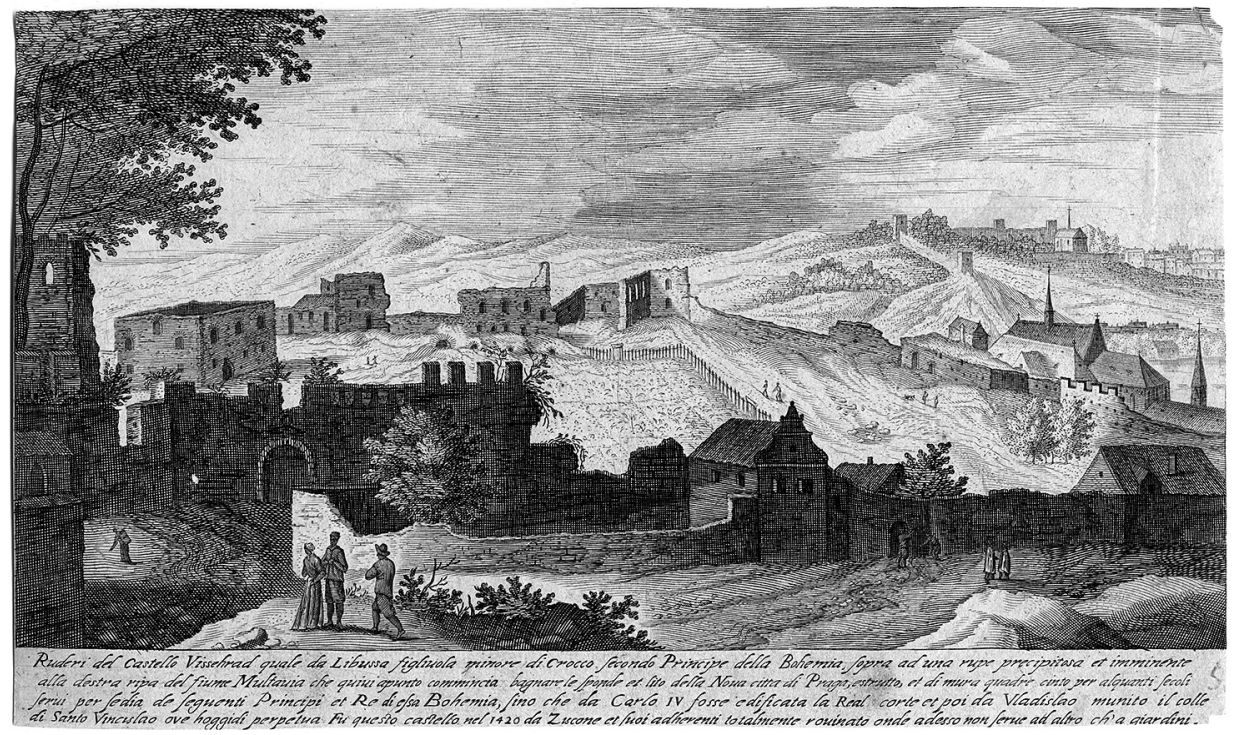

Obr. 1. Tzv. Malé Sadelerovo panorama s pohledem na ruiny karlovského hradu na vyšehradské akropoli od východu. Paláce - vlevo č. 1; uprostřed v zadní části č. 2 a 3; vpravo č. 4. J. Sadeler, mědiryt, 50 . list z publikace Vestigi delle antichità di Roma, Tivoli, 1606. Zdroj archiv autora.

Abb. 1. Sog. kleines Sadeler-Panorama mit Blick auf die Ruinen der Burg von Karl IV. in der Vyšehrader Hauptburg von Osten. Palas - links Nr. 1; in der Mitte im hinteren Teil Nr. 2 und 3; rechts Nr. 4. J. Sadeler, Kupferstich, 50. Blatt aus der Publikation Vestigi delle antichità di Roma, Tivoli, 1606. Quelle Archiv des Verfassers.

téměř detektivní; jako př́iklad lze uvést sondy lokalizované podle polohy kanceláře výzkumu (např. „,ýkop před kanceláŕŕ“"), která se však během třinácti let několikrát přestěhovala. Nikoliv jedinečné, vesměs popisné označení získávaly také zdiva a uloženiny (obr. 2). Uloženiny sice byly v rámci řezu jasně definovány stykovými liniemi a označeny, ale jejich existence jako by byla omezena jen na př́slušný řez, bez pokračování a vztahů k vrstvám zaznamenaným na jiných řezech nebo slovním popisem v denících. Neformální (popisné) označování všech entit (sond, uloženin, zdiv atd.) bylo tehdy obvyklé, ale nebylo výhodné pro práci v terénu (bylo zdlouhavé) ani pro budoucí zpracování výzkumu (způsobuje nejednoznačnosti).

Při rozměřování sond byl nejprve vytyčen základní výkop (liniový nebo na pravoúhlém půdorysu), který pak byl případně rozšiřován různými směry podle toho, kam které nalezené zdi nebo objekty pokračovaly, čímž byl nakonec dosažen výsledný (ne vždy pravoúhlý) tvar sondy. Největší sondy proto najdeme tam, kde bylo nejvíce nálezů, naproti tomu v místech s méně uspokojivými objevy pozorujeme jen menší (,základní“) sondy nebo také vysloveně prospekční a obvykle sériově rozmístěné výkopy o velikosti $1 \times 1$ metr nebo více.

Metodu vykopávek dobře ilustruje použité nářadí. Na fotografiích vidíme dělníky vždy jen s krumpáči a lopatami nebo hrubé stopy krumpáčů na profilech sond (obr. 3). Jako jemnější nástroj se v denících (velmi zřídka) objevují pouze kartáče používané ke konečnému čištění zdiv. ${ }^{6}$ Terénním detailům a ,četbě“ profilů nebyl zjevně přikládán velký význam. Takto výzkum pokračoval až do šesté sezóny. Tehdy, konkrétně 6. června 1929, navštívil vykopávky ředitel Rímsko-germánské komise ve Frankfurtu nad Mohanem Gerhard Bersu (1889-1964) v doprovodu prof. Stockého a mons. Šittlera a - jak do deníku výslovně zaznamenal Jiří Müller - „doporučil uživati ploché motyčky $k$ jemnějši

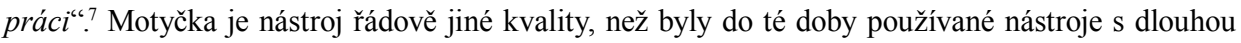

6 Deník 13, s. 24.

7 Deník 10, s. 6-7. 

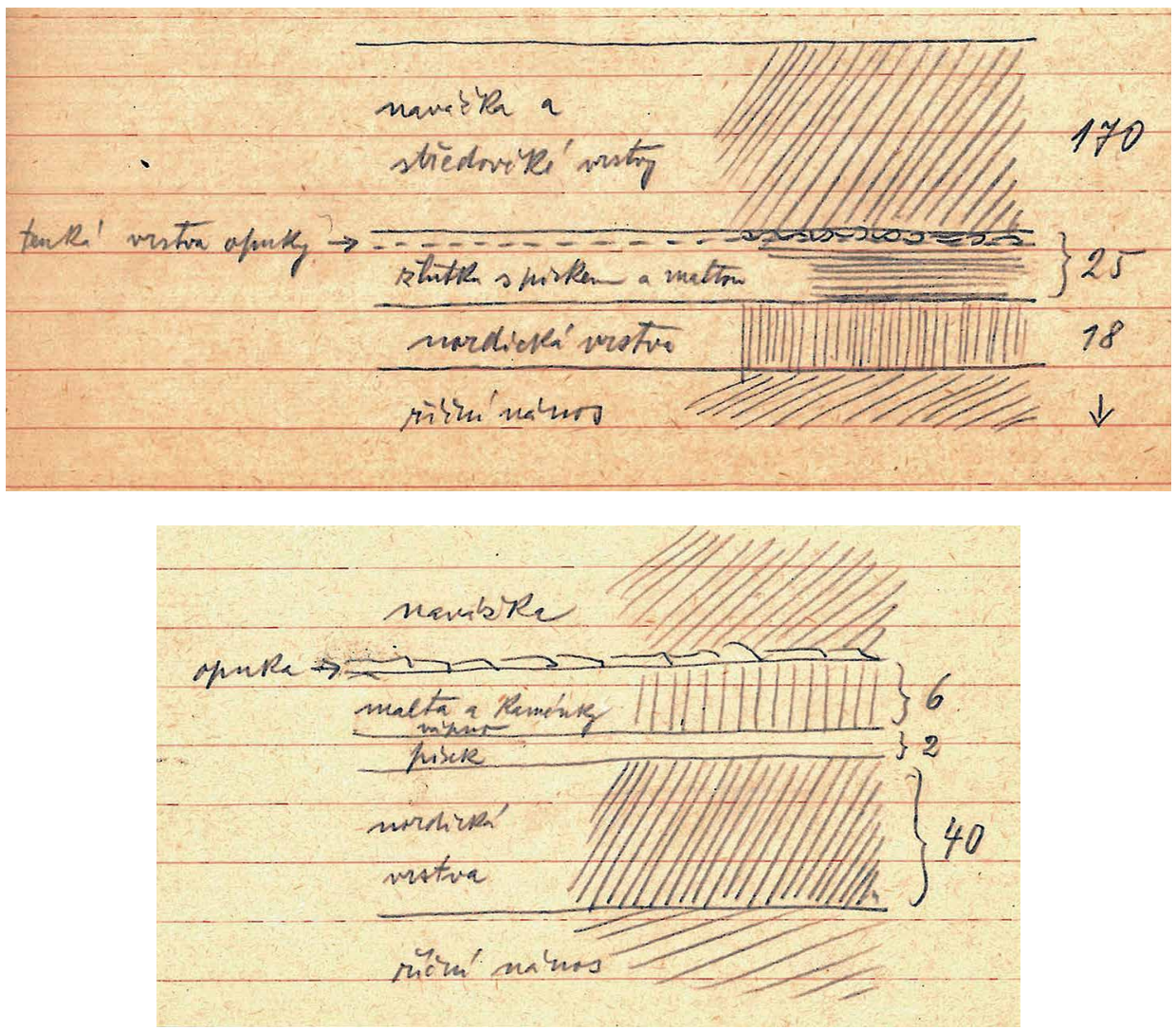

Obr. 2. Ukázky dokumentace profilů z jednoho z deníků vyšehradských výzkumů. Skica - vlevo popis vrstvy a vpravo mocnost v centimetrech. Zdroj Deník 10, s. 4 (nahoře), a Deník 10, s. 8.

Abb. 2. Beispiele einer Profildokumentation aus einem der Vyšehrader Grabungstagebücher. Skizze - links Beschreibung der Schicht und rechts Mächtigkeit in Zentimenter. Quelle Tagebuch 10, S. 4 (oben), und S. 8.

násadou. Dnes samozřejmá a dobře známá výhoda tohoto nástroje, který lze efektivně ovládat pouze $\mathrm{v}$ pokleku či podřepu a který umožňuje vykonávat na zeminu jenom omezený tlak, spočívá v tom, že automaticky mění měřítko archeologické terénní práce a v důsledku dovoluje mnohem snáze odhalovat stratigrafické detaily i drobné nálezy. Nicméně před rokem 1929 nebyla tato znalost českou archeologií zřejmě vůbec osvojena a převratný význam motyčky musel být importován z Německa.

Polohopisně byla většina nálezů dokumentována pomocí pásem od pevných referenčních bodů (rohů budov, zdí apod.) nebo od jiných, již zaměřených nálezů. Př́íslušné údaje byly zaznamenány na náčrtech v terénním deníku, s vyznačením měřených linií a metrických odečtů. Milimetrové papíry se za první republiky na Vyšehradě v terénu zjevně vůbec nepoužívaly. Čím dále ležely nálezy od referenčních bodů (nacházely se od nich třeba až přes deset metrů), tím větší bylo riziko odchylky. Referenční body se navíc mnohdy nacházely i přes metr nad úrovní terénu, což opět zvyšovalo potenciální chybu odečtu (obr. 4). Tento způsob zaměřování byl ale naprosto běžný a musíme ho vzít v potaz při vyhodnocování plánů, jako např́íklad při interpretaci kůlových staveb, přičemž uspořádání kủlových jam nemusí zcela odpovídat skutečnosti. Vertikální poloha nálezů se obvykle měřila hloubkou od povrchu terénu - tedy relativně.

Jen velké nebo trvalejší nálezy (zdiva, větší jámy) byly zaměřovány profesionálním geodetem, který poskytoval i absolutní (nadmořské) výšky. Protože však geodet (a totéž platí i o fotografovi; 

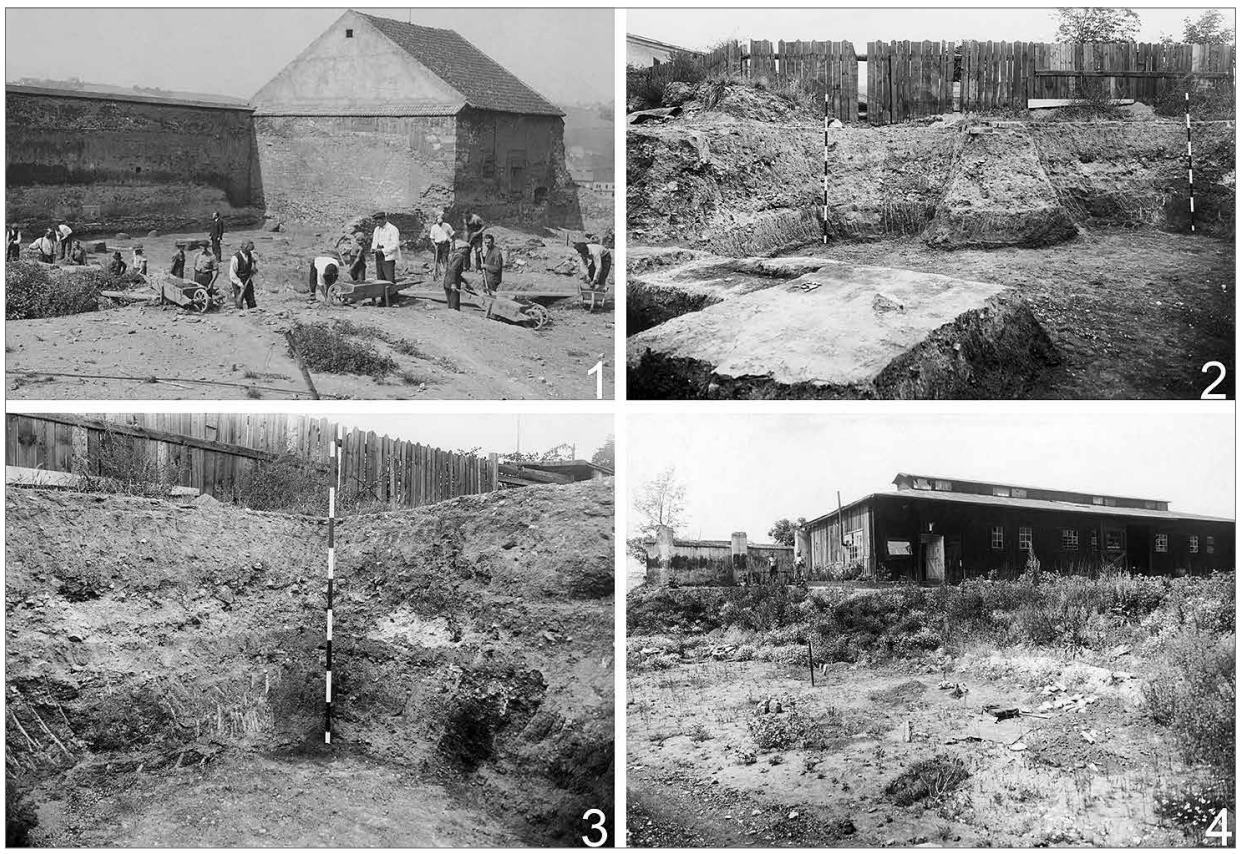

Obr. 3. Fotografická dokumentace výzkumu v letech 1924-1936. 1 - výzkum v sondě 1, pohled od severovýchodu (asi 1927): dělníci a jejich nářadí při práci; 2-3 - dokončená sonda 1/d v pohledu od západu (2) a severozápadu (3), asi 1930: stopy po krumpáčích na profilech; 4 - sonda 1/c od jihovýchodu (1929-1930): po zimní přestávce mohla fotodokumentace zachytit již jen prostor sondy zarůstající vegetací. Zdroj Archiv ARÚ AV ČR, Praha, v. v. i.

Abb. 3. Fotodokumentation der Grabungen in den Jahren 1924-1936. 1 - Grabung in Sondierschnitt 1, Blick von Nordosten (wohl 1927): Handwerker und ihre Werkzeuge bei der Arbeit; 2-3 - fertiger Sondierschnitt 1/d von Westen (2) und Nordwesten (3). Wohl 1930: Spuren von Spitzhacken in den Profilen; 4 - Sondierschnitt 1/c von Südosten (1929-1930): nach der Winterpause konnte die Fotodokumentation nur den Bereich des mit Pflanzen bewachsenen Sondierschnitts erfassen. Quelle Archiv des Archäologischen Instituts, Prag.

obr. 3:4) přicházel na výkopy jen několikrát za sezónu, musely být příslušné objekty ponechávány na místě, zatímco v jejich okolí se výzkum postupně zahluboval. To je zřejmě jedna z původních prŕíčin bizarních ostrůvků zeminy podpírajících kameny nebo jiné nálezy, které se na některých výzkumech v Československu používaly místy až do 80 . let.

Ani při dokumentaci profilů nebyl používán milimetrový papír a uloženiny byly zaznamenávány schematickými kótovanými skicami na stránkách deníků. Zpravidla se zakreslovaly jen základní vrstvy nezř́íka o mocnosti okolo decimetru nebo více (obr. 2). Drobné vrstvičky se objevují jen málo, což - jak dnes na Vyšehradě víme - rozhodně neodpovídá terénní skutečnosti. Znovu se tedy setkáváme s hrubším př́istupem k nálezovým situacím. To má nejméně dva důsledky. Za prvé, dobová dokumentace nutně zachycuje především druhotně přemístěné vrstvy větší mocnosti (zásypy, násypy, planýrky) a velmi často opomíjí tenké primární uloženiny, jako například nášlapové vrstvičky, maltové okapy poblíž zdiv apod., které jsou ovšem pro funkční a chronologickou interpretaci nálezových situací klíčové. Za druhé, v hrubém hledáčku vyšehradských archeologů se zcela ztrácely stratigrafické detaily bazální pro odkrývané zděné relikty (kterým přitom tehdejší archeologové na Vyšehradě přikládali značný význam), zvláště pokud jde o rozlišení vrstev přiléhajících ke zdivu a vrstev zdivem porušených. Pokud tedy vrstva neležela na zdi nebo pod její základovou spárou, nebylo (a dodnes není) možné věrohodně korelovat chronologické svědectví movitých artefaktů s př́íslušnou stavbou.

Jestliže konstatuji, že všechny výše uvedené nedostatky nalezneme u všech asistentů výzkumu bez rozdílu, není to známka individuálních schopností, ale celkového stavu tehdejší české archeologie. Výzkum ostatně pravidelně navštěvovali a dozorovali proslulí univerzitní profesoři 


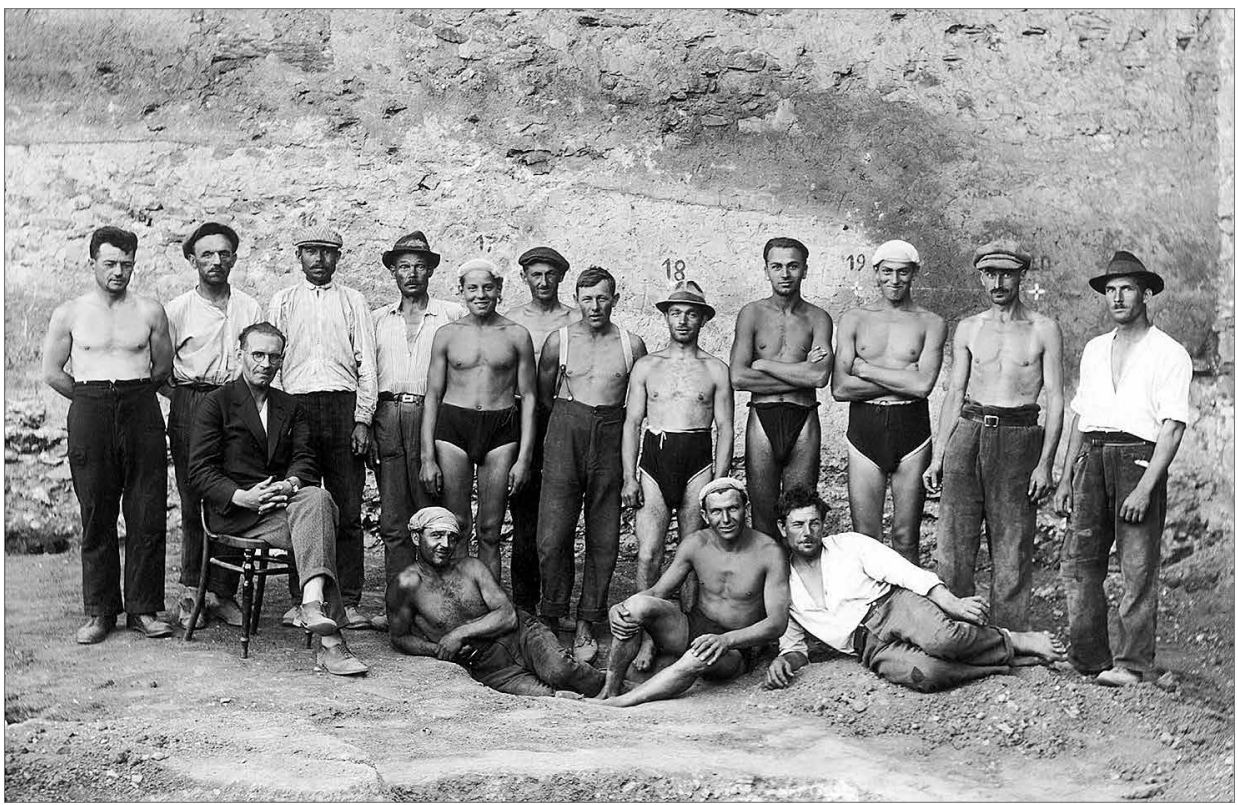

Obr. 4. Prostor sondy 1/a (asi 1928-1929). Dělníci archeologického výzkumu shromáždění před hradební zdí. Na zdi jsou vyznačeny referenční body používané k zaměřování nálezů v ploše dosti rozsáhlé sondy 1 . Zdroj Archiv ARÚ AV ČR, Praha, v. v. i.

Abb. 4. Bereich von Sondierschnitt 1/a (wohl 1928-1929). Vor der Burgmauer versammelte Arbeiter der archäologischen Grabung. An der Mauer sind die für die Vermessung der Funde im flächenmäßig sehr ausgedehnten Sondierschnitt 1 verwendeten Referenzpunkte gekennzeichnet. Quelle Archiv des Archäologischen Instituts, Prag.

a muzejní pracovníci (Moucha-Nechvátal 2015). V české archeologii se první pokus o promyšlené využití uloženin a jejich stratigrafické následnosti pro účely komplexního pochopení nálezové situace setkáváme až v roce 1939 (Borkovský 1941; k tomu Klápště 2016, 9-10), tedy čtyři roky po ukončení vyšehradských výzkumů. Z toho vyplývá otázka, jak vlastně byla naprostá většina prvorepublikových badatelů vyškolena nebo jinak připravena na to, co mají očekávat (a neočekávat) od terénního výzkumu. K tomu ještě jeden prŕíklad z Vyšehradu: Zcela běžné odstraňování středověkých a novověkých terénů pomocí hrubých nástrojů samozřejmě vedlo $\mathrm{k}$ přehlížení drobných nálezů (včetně mincí nebo šperků), kterým byl již tehdy přikládán značný datační význam. Jakmile však byl učiněn nečekaný nález pravěkých „kulturních jam“ v roce 1928, bylo vzápětí zavedeno plošné prosívání hlíny na sítech kvůli „drobným úlomkům nožíků z křemene a pazourku“. ${ }^{8}$ Samozrejmě není nutné dokládat, že síta by byla velmi užitečná i př̀i výzkumu středověkých uloženin.

\section{Diskuse a závěr}

Co studium terénní dokumentace a dalších archiválií týkajících se vyšehradské kampaně vypovídá o tehdejším stavu české archeologie? Rychle dospějeme k závěru, že pro uskutečnění tohoto státem zadaného úkolu vynaložili naši předchůdci mimořádné úsilí, které se po třináct let muselo vyrovnávat s trvalými finančními, organizačními, technickými a personálními problémy. V metodické rovině byl tento projekt uskutečněn na dobové úrovni, kterou nicméně neposunul na vyšší prríčku.

Druhou otázkou je společenská role archeologie. Výše citovaný článek od Jaroslava Böhma v Lidových novinách z roku 1924 byl nepochybně jednou z prŕíležitostí archeologie blýsknout se před širokou československou veřejností a takříkajíc ohřát si svou polívčičku. V úvodu se sice sebevědomě

8 Deník 9, s. 24. 
hovoří o české, teoreticky důkladně vybavené archeologii, které se znenadání naskytla př́iležitost ukázat, co umí. V následujících pasážích ale text věcným až téměř zpravodajským tónem podává získané poznatky a jmenuje budoucí úkoly, aniž by jen v náznaku manipuloval s národním nebo jiným symbolickým kapitálem Vyšehradu, což by přitom v dané době nebylo obtížné (viz argumentace J. Liera v úvodu). K podobnému závěru vedou i všechny ostatní početné soudobé texty od některého z aktérů vyšehradských výzkumů určené pro širokou veřejnost, které se mi dostaly do rukou. Platí to také o neoficiálních úředních dokumentech, v nichž zpravidla Komise podává různým státním institucím zprávu o své činnosti, $\mathrm{k}$ níž autoři velmi často byli nuceni připojovat prosbu o další finanční subvenci; ačkoliv právě v těchto materiálech by byl nějaký apel na společenský význam výzkumu pochopitelný, vůbec se v nich neobjevuje. V uctivých dokumentech zasílaných do kanceláře prezidenta T. G. Masaryka se archeologů zmocnily emoce pouze jednou - v př́ípadě nečekaného objevu pravěkých pozůstatků, které ovšem s národními dějinami neměly nic společného. Po prostudování všech dokumentů, včetně rozsáhlé terénní dokumentace, lze získat neodbytný pocit, že prvořadým zájmem našich předchůdců byly odborné otázky, kterými byli skutečně plně zaujati. Abych tedy odpověděl na otázku z úvodu, zda nacionalistická nebo nějaká jiná politická „karta“ sehrávala při výzkumu na Vyšehradě za první republiky nějakou roli, pak konstatuji, že tomu nic nenasvědčuje.

Text vznikl v rámci projektu reg. č. 18-16362S „Počátky Vyšehradu. Archeologie a vznik předního politického centra raného českého státu“, podpořeného Grantovou agenturou České republiky.

\section{Prameny a literatura}

BORKOVSKÝ, I., 1941: Soběslavská hradba v Rožmberském paláci na Pražském hradě, ZPP V, 113-123.

DENÍK: Terénní deníky z archeologického výzkumu na Vyšehradě, sv. 1-16, různí autoři, ulož. v Archivu ARÚ AV ČR, Praha, v. v. i.

JEŽKOVÁ, P., 2012: Výšiny Vyšehradu ohrožené nízkou bestií. Z listů, manifestů a fejetonů přelomu 19. a 20. věku. In: Královský Vyšehrad IV, 427-446. Praha.

KLÁPŠTĚ, J., 2016: The archaeology of Prague and the medieval Czech Lands, 1100-1600. Sheffield - Bristol. MOUCHA, V.-NECHVÁTAL, B., 2015: Dějiny a metody archeologického výzkumu. In: Moucha, V.-Nechvátal, B.-Varadzin, L. et al., Vyšehrad. Knížecí a královská akropole. Svědectví archeologie, 23-48. Praha.

RUFFER, V., 1861: Historie vyšehradská neb vypravování o hradu, o kapitole a městu hory Vyšehradu u Prahy v království Českém. Praha.

VARADZIN, L., 2015: Archeologická sondáž. In: Moucha, V.-Nechvátal, B.-Varadzin, L. et al., Vyšehrad. Knížecí a královská akropole. Svědectví archeologie, 49-69. Praha.

\section{Zusammenfassung}

\section{Die Archäologischen Grabungen auf dem Vyšehrad in den Jahren 1924-1936}

Die im Jahr 1924 aufgenommenen Grabungen auf dem Vyšehrad, die durch eine Revitalisierung der in die Form eines öffentlichen Parks gebrachten barocken Festung hervorgerufen wurde, war eine der größten in der Tschechoslowakei durchgeführten systematischen Grabungen der Zwischenkriegszeit. Mit ihrer Durchführung wurde das Staatliche Institut für Archäologie (dem Vorgänger des heutigen Archäologischen Instituts der Akademie der Wissenschaften der Tschechischen Republik) betraut, das auch die Finanzierung gewährleisten sollte. Man gründete eine Kommission für die Erforschung des Vyšehrads, die aus 31 Vertretern aus 16 verschiedenen Institutionen bestand, an deren Spitze K. Guth, A. Stocký, K. Buchtela, R. Hlubinka und E. Šittler standen. Die Geländearbeiten wurden von frisch diplomierten Archäologieabsolventen der 
Karls-Universität geleitet (J. Böhm, J. Filip, M. Grbić, S. F. Svoboda, J. Vacek und J. Müller). Mit den Ausgrabungen wurde an mehreren Stellen gleichzeitig begonnen: an den romanischen Bauten (St. Martinsrotunde, St. Laurentius-Basilika), auf der Hauptburg und an anderen Stellen. Im Falle der damals archäologisch völlig unbekannten Hauptburg (ca. $20000 \mathrm{~m}^{2}$; letztendlich wurden 67 Sondierschnitte über eine Gesamtausdehnung von $4400 \mathrm{~m}^{2}$ gelegt) ging den Grabungen eine sorgfältige Recherche in den schriftlichen und ikonographischen Quellen voraus (Abb. 1).

Eine jeweils grundlegende Ausgrabung wurde immer abgesteckt und dann gegebenenfalls in verschiedene Richtungen erweitert, je nachdem in welche Richtung eine jeweils entdeckte Mauer oder die Objekte weiterführten (die größten Sondierschnitte findet man deshalb dort, wo es die meisten Funde gab). Man verwendete grobe Gerätschaften mit langem Stil (Spitzhacken und Schaufeln; die groben Spuren der Spitzhacken sind auch an den Schnitten zu sehen, siehe Abb. 3); zur abschließenden Säuberung der Mauerwerke wurden Bürsten verwendet. Diese Praxis änderte sich erst am 6. Juni 1929, als der Direktor des RGK in Frankfurt am Main Gerhard Bersu die Ausgrabungen besuchte und empfahl, für die feineren Arbeiten Flachhacken zu benutzen. Für die damalige Zeit typisch war es, Sondierschnitte, Mauerwerke und Schichten (Abb. 2) formlos, beschreibend und uneinheitlich zu kennzeichnen, was für die Arbeit im Gelände langwierig und für eine künftige Bearbeitung der Ausgrabung Uneindeutigkeiten zur Folge haben konnte. Die Lagebeschreibung der meisten Funde erfolgte durch ihre Vermessung mittels eines Streifens von festen Referenzpunkten (Abb. 4) und durch ihre Dokumentation mit auf den Seiten des Geländetagebuchs schematisch kotierten Skizzen. Ein Geodät (das gleiche gilt auch für den Fotografen; Abb. 3:4) kam nur einige Male während der Saison zu den Ausgrabungen, sodass die entsprechenden Objekte über mehrere Wochen oder auch Monate an der Stelle so belassen werden mussten wie sie gerade waren, während in ihrer Umgebung nach und nach immer tiefer gegraben wurde, weswegen Inseln mit Erdreich entstanden, die Relikte von Konstruktionen, Gruben und weitere Funde in sich bargen. Millimeterpapier wurde im Gelände offenbar überhaupt nicht verwendet. In den Profilen hat man eher nur deutlichere und mächtigere Schichten aufgezeichnet, wobei kleine Schichten zahlenmäßig unterrepräsentiert sind. Die Existenz von Schichten erscheinen in der Dokumentation so als ob sie nur auf einen jeweiligen Schnitt beschränkt worden seien, ohne ihre Weiterführung und Bezüge zu woanders verzeichneten Schichten zu verfolgen. Für die Freilegung von gemauerten Relikten elementare stratigraphische Details hat man völlig übergangen, und die Störung von Schichten durch ein Mauerwerk, oder umgekehrt, ihr Anliegen an einem Mauerwerk, wurden nicht verfolgt.

Die nähere Betrachtung des Verlaufs und der Methodik der 1924-1936 auf dem Vyšehrad durchgeführten Grabungen führt zu der Frage, wie die damaligen tschechischen Forscher ausgebildet oder auf andere Weise dazu vorbereitet wurden, was sie von einer Geländegrabung erwarten (und nicht erwarten) konnten. In der tschechischen Archäologie taucht der erste Versuch einer durchdachten Ausnützung von Schichten und ihrer stratigraphischen Aufeinanderfolge zwecks komplexem Verstehen einer Fundsituation erst im Jahr 1939 auf (Borkovský 1941; dazu Klápště 2016, 9-10).

Der vorliegend Text entstand im Rahmen des von der Förderagentur der Tschechischen Republik geförderten Projektes Reg. Nr. 18-16362S ,Die Anfänge des Vyšehrad. Die Archäologie und die Entstehung eines führenden Zentrums des frühen böhmischen Staates“.

Mgr. Ladislav Varadzin, Ph.D., Archeologický ústav AV ČR, Praha, v. v. i., Letenská 4, 11801 Praha, Česká republika,varadzin@arup.cas.cz 
